\title{
Nephrosis-deafness-urinary tract-digital malformations syndrome
}

INSERM

\section{Source}

INSERM. (1999). Orphanet: an online rare disease and orphan drug data base. Nephrosisdeafness-urinary tract-digital malformations syndrome. ORPHA:2669

Nephrosis-deafness-urinary tract-digital malformations syndrome is characterised by anomalies of the urinary tract, thumbs and big toes, deafness and nephrosis. It has been described in five brothers. The mode of transmission has not been clearly established but seems to be either autosomal recessive or X-linked dominant. 